NBER WORKING PAPER SERIES

TAX POLICY AND

INTERNATIONAL COMPETATIVENESS

Lawrence $H$. Summers

Working Paper No. 2007

NATIONAL BUREAU OF ECONOMIC RESEARCH

1050 Massachusetts Avenue

Cambridge, MA 02138

August 1986

I have benefited from useful discussions with Richard Cooper, Rudi Dornbusch, and Jeff Sachs. This paper draws in part on earlier joint work with John Earle. I am indebted to Fernando Ramos and Mark Sundberg for valuable research assistance. This paper is forthcoming in the NBER conference volume International Aspects of Fiscal Policies (ed. J. Frenkel). The research reported here is part of the NBER's research program in Taxation. Any opinions expressed are those of the author and not those of the National Bureau of Economic Research. 
Working Paper \#2007

August 1986

Tax Policy and International Competitiveness

\author{
ABSTRACT
}

This paper examines the interactions between tax policy, international capital mobility, and international competitiveness. It demonstrates that tax policies which stimulate national investment without affecting national savings must inevitably lead to deterioration in country's trade balance in the shortand intermediate run. This conclusion, which contradicts a great deal of popular rhetorichighlights the importance of considering the macroeconomic as well as the microoconomic aspects of tax changes.

More generaliy, the effects of tax policies depend criticaliy on the extent of the international capital flors which they generate. The paper examines the issue of international capital mobility both thooreticaliy and empiricaliy. A variety of considerations sugest that while tax policies could generate large capital flors, gorernments pursue policies whioh tend to inhibit capital flows following tax changos. This makes the analysis of tax policies difficult. 
International considerations are coming to play an increasingly important role in U.S. tax policy debates. Policy discussions of tax provisions bearing on foreign investment in the United States and American investment abroad has long focused on the competitiveness question. Recently reductions in taxes on business investment have been advocated on the grounds that they will increase American competitiveness. Excessive tax burdens are frequently blamed for the poor international performance of some American industries. Indeed the President's Commission on International Competitiveness recently urged business tax relief as a major element in a strategy directed at improving the trade position of the United States. Tax increases to reduce looming budget deficits are often defended on the grounds that they will reduce trade deficits.

While economists have long recognized that increased international competitiveness is not necessarily a good thing, because it is the mirror image of a decline in a nation's terms of trade, it is nonetheless an important policy goal. An analys is of the interrelationships between tax policy and competitiveness therefore seems worthwhile. This paper provides such an analysis stressing the crucial role of capital mobility in determining the impact of tax reforms on an economy's traded goods sector. I begin by examining theoretically the relationship between tax changes and competitiveness under various assumptions about international capital mobility. Finding the conclusions sensitive to assumptions about capital mobility, I go on to consider empirically the extent of international capital mobility. Drawing on both the theoretical and empirical analysis, I attempt 
to assess the likely impact of alternative tax reforms on international competitiveness.

The common assumption that capital flows freely internationally leads to striking conclusions regarding the effects of tax policies. Tax measures which stimulate investment but do not affect savings will inevitably lead to declines in international competitiveness as long as capital is freely mobile internationally. The economic mechanism is simple. Measures which promote investment attract funds from abroad leading to an appreciation in the real exchange rate and a reduction in the competitiveness of domestic industry. The accounting identity holding that the current account equals the difference between national savings and national investment insures that increases in investment ceteris paribus will be associated with decreases in the trade balance. Conversely tax policies which promote savings but do not have a direct impact on investment will improve trade performance.

These results challenge the commonly expressed view that reductions in tax burdens on business will improve competitiveness by enabling them to undertake more productivity enhancing investment. They also raise an interesting question in political economy. Why do firms in the traded goods sector whose competitivenests will be hurt by the capital inflows associated with investment incentives lobby in favor of them? Consideration of this question leads naturally to an examination of the premise of free international capital mobility which underlies the arguments in the previous paragraph. If capital is not internationally mobile, stimulus to investment will not lead to capital inflows and therefore will not be associated with trade balance deterioration. 
While there certainly is a large pool of internationally mobile capital, Feldstein and Horioka (1980) and Feldstein (1983) have pointed out an important puzzle raised by the hypothesis of perfect international capital mobility. This hypothesis would predict that there should be no systematic relationship between domestic saving and investment rates, since capital can flow freely. Yet looking across the OECD nations there is a very strong positive correlation between savings and investment rates. Looking over long periods of time cumulative current account deficits or surpluses are quite small despite large variations in domestic savings rates. On a very consistent basis, high savings countries are also high investment countries while low savings countries like the United States have relative low rates of investment.

The observation that domestic savings and investment rates are strongly associated can be interpreted as suggesting tax policies which raise savings are likely to significantly increase domestic investment. Similarly, policies directed at investment are unlikely to lead to permanent increases in invèstment unless domestic savings are increased as well. Alternatively, as many international economists argue, the cross-sectional correlation between national savings and investment rates may be a statistical artifact which does not call into question the international mobility of capital. Resolving the issue requires that some interpretation of the close cross-sectional linkages between national savings and investment be provided.

I consider three alternative hypotheses regarding the apparent international immobility of capital. The first is the hypothesis advanced by Feldstein and Horioka that institutional and legal restrictions of a variety 
of types preclude substantial international capital flows. Second is a possibility advanced by Obstfeld (1985) among others that the high correlation between domestic savings and investment rates is an artifact of common factors such as high population growth which affect both savings and investment. The third hypothes is is that capital is mobile internationally but that countries systematically utilize economic policy tools in an effort to achieve approximate current account balance so that large sustained capital flows are not observed. My conclusion is that the third hypothesis provides the most satisfactory available explanation for the observed correlations between domestic savings and investment rates. I suggest several reasons why countries might find it desirable to maintain external balance.

This conclusion raises an important question. Given that policies to limit net capital mobility are frequently pursued, how should the effects of tax policy reforms which affect savings or investment be evaluated? If no other policy measures are undertaken, their effects should be analyzed under the assumption that capital is perfectly mobile. But the historical record suggests that current account imbalances are likely to be offset by other policy actions. Both these issues have obvious relevance to the current American situation where business tax reductions appear to have stimulated a significant amount of capital formation and drawn capital in from abroad in large quantity; but where the trade deficit is seen as a major problem.

The paper is organized as follows. The first section examines theoretically the effects of alternative tax policies on competitiveness under Different assumptions about international capital mobility. It suggests some possible explanations for the paradox that firms in traded goods industries 
frequently support tax policies that seem likely to reduce competitiveness. The second section takes up the question of the extent of international capital mobility and documents the very high correlation between domestic savings and investment rates across the OECD nations. The third section considers alternative hypotheses regarding this phenomenon and concludes that it is most likely the result of national economic policies directed at maintaining external balance. Possible reasons why nations might pursue such policies are considered. The fourth and final section considers the implications of the results for tax policy in general and the current American situation in particular.

\section{Tax Policy in an Open Economy}

This section examines theoretically the effects of various tax policies in an open economy where capital is mobile. In considering taxation in an open economy it is crucial to distinguish between taxes on savings and investment. As I use the terms here, taxes on savings refer to taxes on capital income received by home country residents regardless of where the capital is located. The U.S. interest income tax is an example of such a tax. Conversely, taxes on investment refer to taxes levied on capital within the home country regardless of its ownership. The corporate income tax is an example of an investment tax. In closed economies it is clear that there is no important difference between savings and investment taxes. But in open economies where capital flows are possible they will have quite different effects. The model presented be low makes it possible to analyze the short and 
long run effects of both pure savings and investment taxes. There are a variety of complexities involved in mapping real world tax structures with their complex foreign tax credit and deferral provisions into the pure savings and investment taxes treated here. I bypass these problems.

The main conclusions of the formal analys is presented below may be motivated by considering the national income accounting identity $S-I=X-M$. This identity holds that the trade balance $(X-M)$ must equal the excess of domestic savings over investment. Equivalently, as the balance of payments must balance, the current account $(X-M)$ must be just offset by the capital account $(S-I)$. It is apparent from this identify that policies which increase national investment without increasing national savings must necessarily lead to increases in imports or decreases in exports. In either event, the traded goods sector of the economy will contract. Conversely policies which increase national savings without affecting national investment will improve the current account and, in a fully employed economy, lead the traded goods sector to expand.

These results apply in the short and intermediate run. Ultimately, they will be reversed. Consider again the case where investment is increased with no change in savings. Foreigners who finance the excess of investment over savings will accumulate claims on the domestic economy. Ultimately these claims must be paid back and this will require that the home country run a trade surplus, exporting more than it imports. Similarly, increases in domestic savings without changes in investment will lead ultimately to trade deficits as domestic residents liquidate their claims on foreign economies. 
Figure 1

The Long Run Effects of Corporate 'Tax Increase

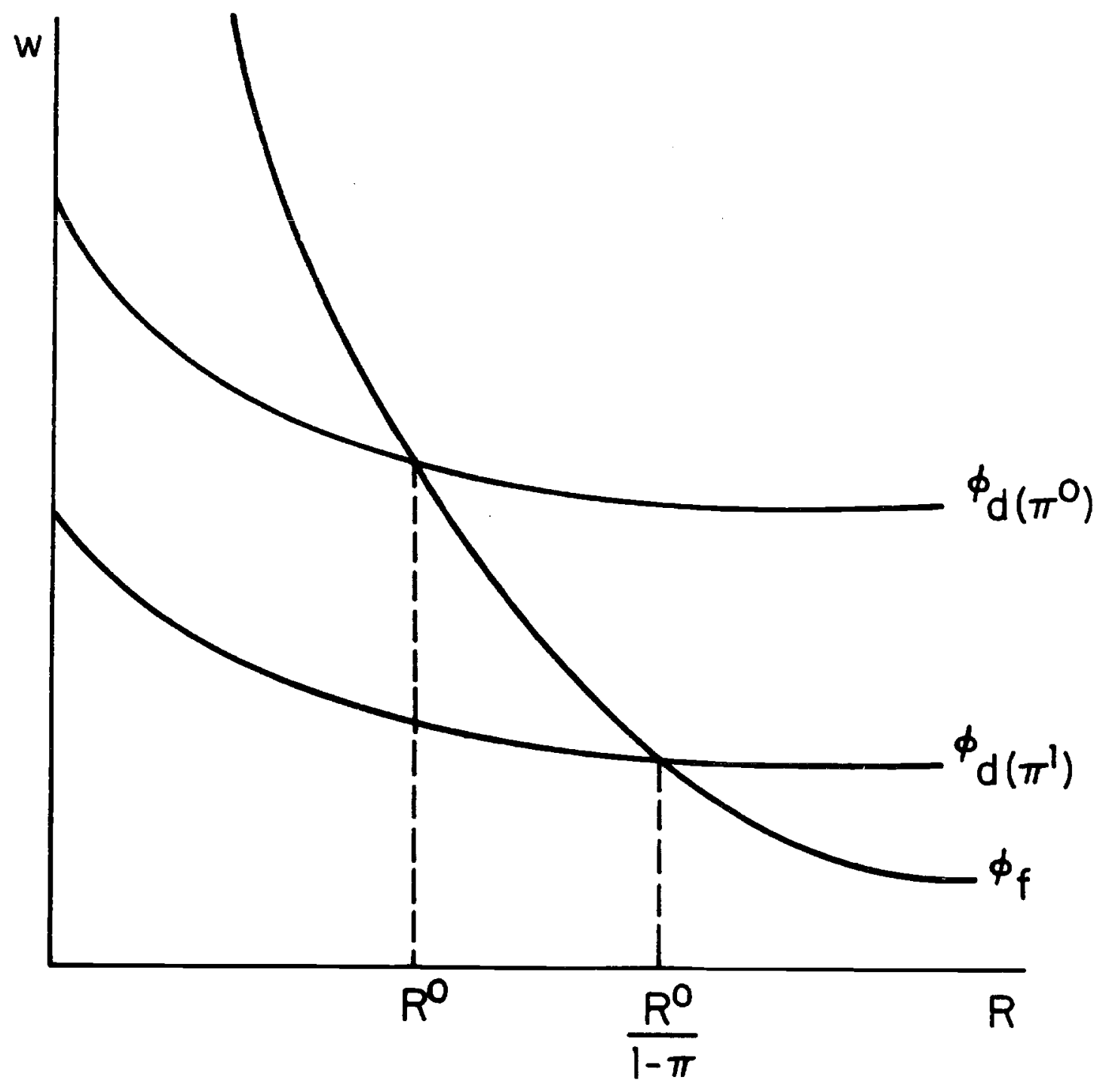


Modelling the Linkages between Tax Policy and Competitiveness

While a number of studies, notably Feldstein and Hartman (1980) and Hartman (1983) have examined the effects of tax policy on capital intensity, they have assumed that there is only one internationally produced good making it impossible to study issues relating to competitiveness. Goulder, Shoven and Whalley (1983) examine the implications of international capital mobility within the context of a computable general equilibrium model and show that international considerations can have important implications for tax policy. Because the model they consider is not grounded in intertemporal optimization, it is not possible to distinguish the short and long run effects of tax policies. Lipton and Sachs (1983) examine a two country growth model with two sectors producing traded and non-traded goods and with an investment function based adjustment costs. Their model is sufficiently complex that it must be solved by numerical simulation.

Here I follow very closely Bruno (1982) and less closely Sachs (1981, 1982) in considering a two period model in which the first period corresponds to the short run and the second period corresponds to the long run. Consideration of a more realistic infinite horizon model would be analytically intractable. I treat the case of a small open economy which takes both the price of the traded good and the interest rate as given. The analysis could be modified to treat the case of an economy large enough to affect world markets.

Consider a two commodity, two period framework. Tradeables $Q_{f}$ are produced in each period according to the production function $Q_{f}^{t}=Q_{f}\left(L_{f}^{t}, K_{f}^{t}\right)$ which is assumed to have constant returns to scale. The non-tradeable domestic good $Q_{d}$ is produced with the constant returns to scale production 
function $Q_{d}^{t}=Q_{d}\left(L_{d}^{t}, K_{d}^{t}\right)$. The price of tradeables is taken as the numeraire and price of the domestic good is denoted $\pi$. Increases in $\pi$ correspond to real appreciations of the local currency. Production of tradeable goods is allocated between consumption $C_{f}$, investment $I$, and net exports $X$ which may be negative. Production of non-tradeable goods is divided between private consumption $C_{d}$ and public consumption $G$. It is examined further below. The assumed sectoral specialization of investment and government spending simplifies the analysis, and does not alter the basic conclusions.

Total labor supply in each period is fixed at $L^{-t},\left(L^{t}=L_{d}^{t}+L_{f}^{t}\right)$. Total capital is fixed in the first period and cannot be reallocated between sectors. First period investment or disinvestment augments the second period capital stock. $\left(K_{d}^{2}-\bar{K}_{d}+K_{f}^{2}-\bar{K}_{f}=I\right)$. Since for simplicity it is assumed that capital does not depreciate, it is reasonable to allow I to be negative. No new capital goods are produced in the second period since it represents posterity.

Firms maximize the present value of after corporate tax profits:

$$
P V=(1-\tau)\left[Q_{f}^{1}+\pi^{1} Q_{d}^{1}-w^{1} L^{1}+R^{-1}\left(Q_{f}^{2}+\pi^{2} Q_{d}^{2}-w^{2} L^{2}\right)\right]-I^{1}
$$

where $R=(1+r)$. Note that since capital does not depreciate the firm is allowed no tax depreciation allowances. Maximization subject to the production functions and factor accumulation constraints yields standard first order conditions:

$$
\pi \frac{\partial Q_{d}^{t}}{\partial L_{d}^{t}}=\frac{\partial Q_{f}^{t}}{\partial L_{f}^{t}}=w^{t} \quad t=1,2
$$




$$
R=(1-T) \pi^{2} \partial Q^{2} / \partial K_{d}^{2}=(1-\tau) \partial Q_{f}^{2} / K_{f}^{2}
$$

where equality of first period marginal products at the point $k_{d}$, $K_{f}$ has been assumed. 1

At this point, we are ready to examine the implications of a corporate tax change for factor and product prices in the long run. Figure 1 depicts the factor price frontiers in the two sectors under the assumption that the traded goods sector is more capital intensive. Production occurs at the intersection of the two frontiers. The relative price of the non-traded good, $\pi$, shifts until the factor price frontiers intersect at the world interest rate. Now consider a corporate tax increase. The factor price frontier for the tradeable good does not shift but the required pre-tax return on capital is increased from $R^{0}$ to $R^{0} / 1-T$. This necessitates a change in $\pi$ to shift the domestic goods factor price frontier. It is clear from Figure 1 that under our assumption that the traded good sector is more capital intensive than the non-traded goods sector, a corporate tax will lower capital intensity in both sectors and reduce the relative price of domestic goods, thereby causing the traded goods sector to contract. The last result would be reversed if the opposite factor intensity assumption was maintained.

Leamer (1980) presents some rather dated evidence on the relative capital intensities of U.S. traded and non-traded goods in the context of a study of the Leontief paradox. His data, drawn from Leontief's original work, indicate that the traded goods sector is much more capital intensive than the non-traded goods sector. However he notes that the more recent data provided in Baldwin (1971) suggests the opposite conclusion. At present, I am unaware 
of more satisfactory evidence on this question for the United States. It seems appropriate to be agnostic in the relative capital intensity question and to conclude that capital intensity effects will not lead to large effects of tax policies on the long run composition of national output.

As just demonstrated, it is possible to examine the impact of a corporate tax change on factor and product prices in the long run without specifying anything about product demands. In order to address the sectoral composition of output and employment, and to consider short run issues, it is necessary to specify how demand is determined. For simplicity, I assume that consumers maximize a Cobb-Douglas utility function:

$$
U=\alpha 1 n c_{f}^{1}+(1-\alpha) 1 n c_{d}^{1}+D\left[\alpha 1 n c_{f}^{2}+(1-\alpha) 1 n c_{d}^{2}\right]
$$

where $D$ is a discount factor, and $\alpha$ is the share of consumption-expenditure devoted to the foreign good.

Households maximize utility subject to their budget constraint which holds that:

$$
C_{f}^{1}+\pi^{1} c_{d}^{1}+[(1-\theta) R]^{-1}\left(C_{f}^{2}+\pi^{2} c_{d}^{2}\right)=\Omega
$$

where $\Omega$ represents the present value of their endowment in terms of the foreign good, and $\theta$ is the tax rate levied on savings. Net household wealth $\Omega$ is given by:

$$
\Omega=\left(Q_{f}^{1}+\pi^{1} Q_{d}^{1}\right)+[(1-\theta) R]^{-1}\left(Q_{f}^{2}+\pi^{2} Q_{d}^{2}\right)-T-I
$$

where $T=T^{1}+R^{-1} T^{2}=\pi^{1} G^{1}+R^{-1} \pi^{2} G^{2}$ is the total cumulative revenue of the government. Since $C_{d}^{t}+G^{t}=Q_{d}^{t}$, it follows that:

$$
\Omega=Q_{f}^{1}\left(\pi^{1}\right)+\pi^{1} c_{d}^{1}+\left([(1-\theta) R]^{-1} w^{2} L^{2}-[(1-\theta) R]^{-1} \pi^{2} G^{2}+\bar{K}_{d}+\bar{K}_{f}\right)
$$


Figure 2

The Determination of Long Run Equilibrium

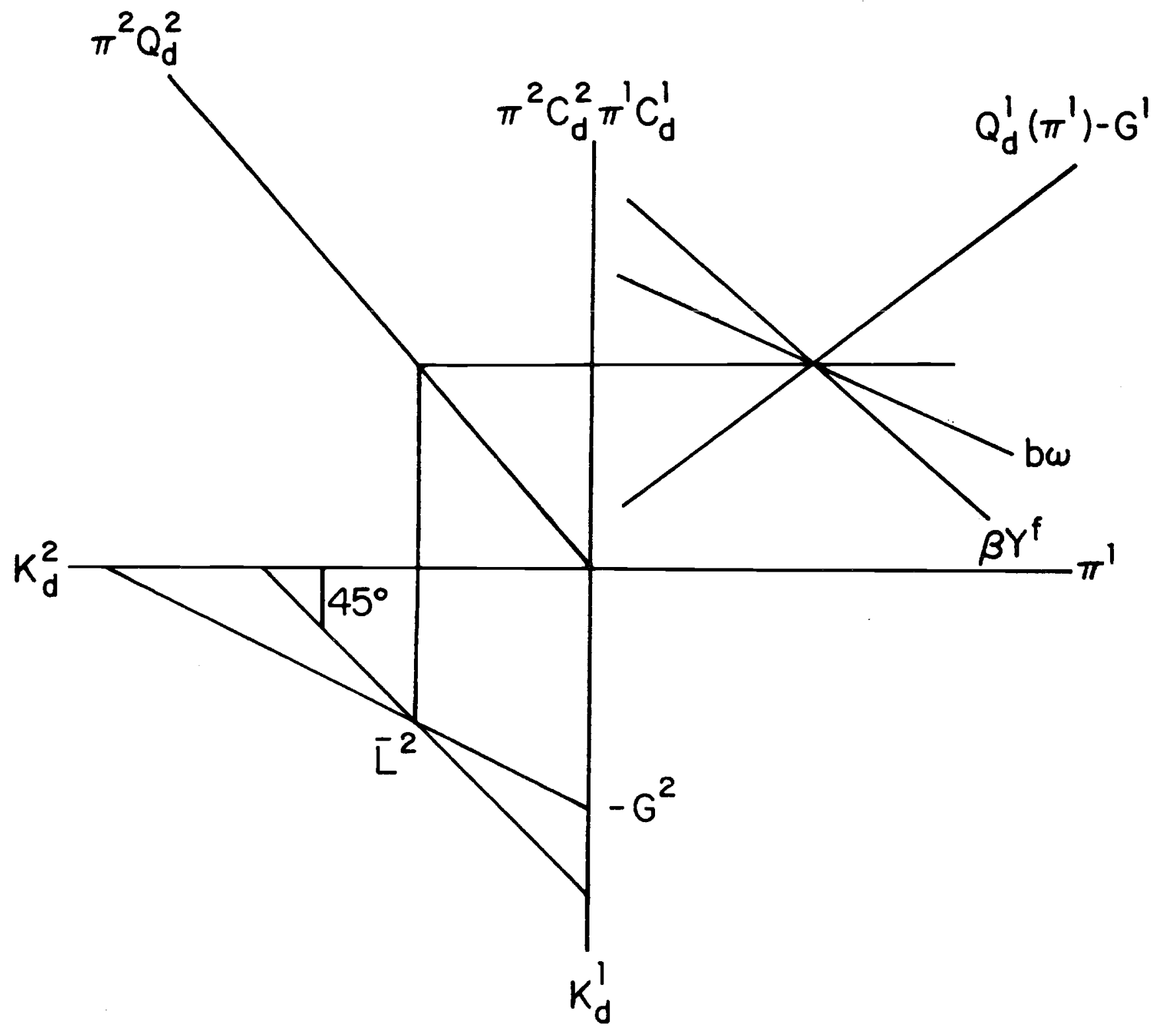


where it can be assumed that $Q_{f}$ is a negative function of $\pi^{1}$.

At this point we are ready to solve the model using the very ingenious graphical technique developed in Bruno (1982). Equation (6) and the assumption of Cobb-Douglas utility imply that:

$$
\pi^{1} C_{d}^{1}=b \Omega\left[\pi^{1}, R(1-\theta) G^{2}\right]
$$

The $b \Omega$ function is negatively related to all three of its arguments. It is plotted as the line marked $b \Omega$ in Figure 2. In order to characterize first period equilibrium we add a supply function for the total value of $C_{d}$ :

$$
\pi^{1} C_{d}^{1}=\pi^{1} Q_{d}^{1}\left(\pi^{1}\right)-\pi^{1} G^{1}
$$

This curve is also depicted in quadrant I of Figure 2.

Together these two schedules already permit us to characterize the determination of first period equilibrium. Note that any policy which reduces first period consumption such as a reduction in the individual tax rate $\theta$, will lead to a reduction in $\pi^{1}$ and an increase in the size of the tradeable goods sector. Likewise a decrease in public consumption will lead to a reduction in $\pi$, and an increase in competitiveness.

In what follows it will be useful to examine the behavior of domestic savings $s$. Note that $s_{1}=Y_{f}-C_{f}^{1}$. Given our assumption of Cobb-Douglas utility, $C_{f}^{1}$ is proportional to $\pi c_{d}^{1}$. Drawing in the schedule $\beta Y_{f}\left(\pi_{1}\right)$ where $\beta=(1-\alpha) /(\alpha)$, we can see that savings is proportional to the vertical distance between this schedule and the $b \Omega$ schedule. Note that the $\beta Y^{f}$ schedule is steeper than the $b \Omega$ schedule because $b<\beta$.

We are now ready to consider second period equilibrium and the 
Figure 3

The Effect of a Savings Incentive

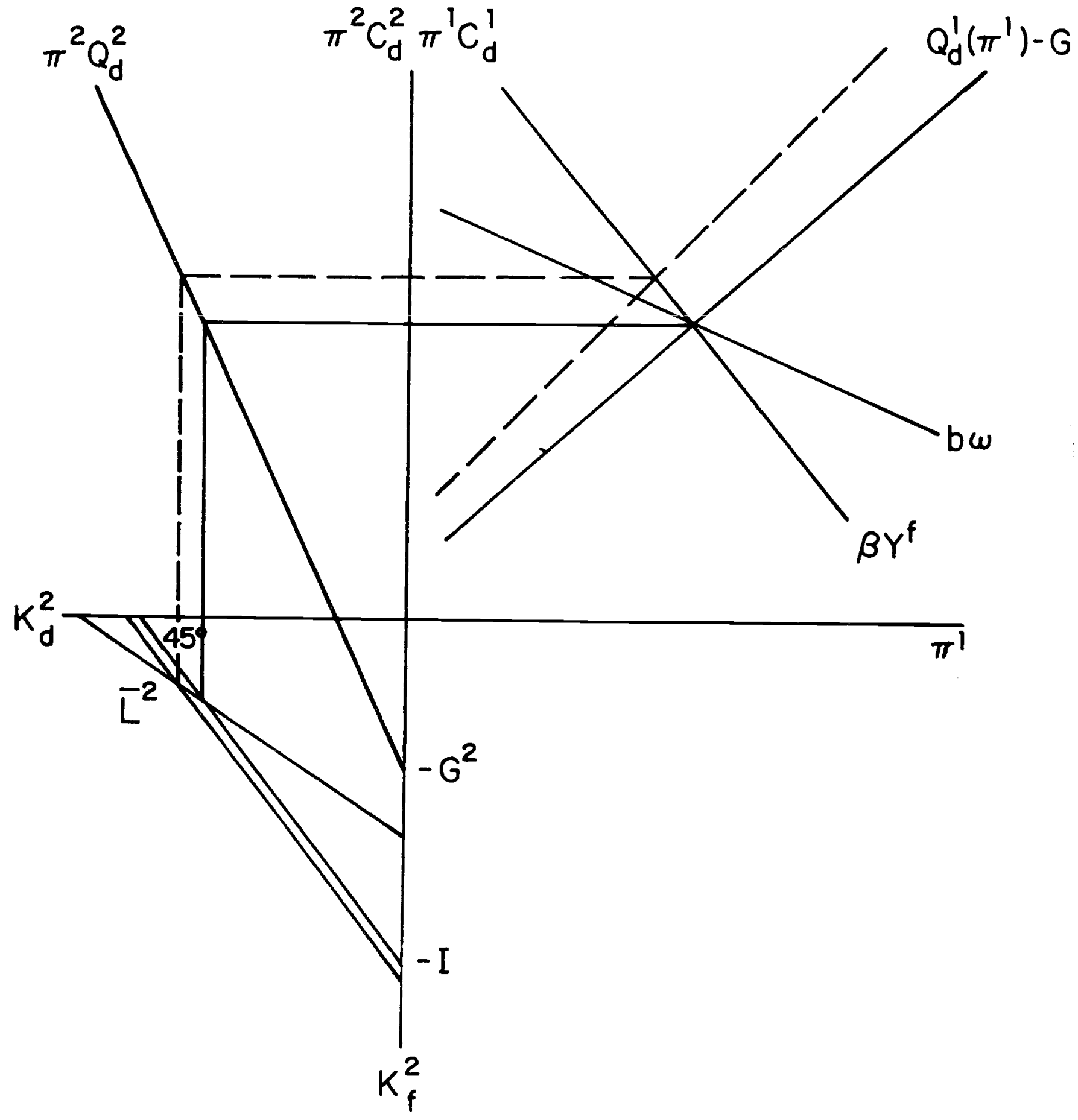


determination of investment. The determination of second period factor and product prices has already been discussed. These serve to uniquely determine capital-labor and capital-output ratios in both sectors. In quadrant 2 of Figure 2, the relationship between $\pi^{2} c^{2} d$ and $k^{2}$ is depicted. The slope of this schedule increases with the period 2 capital output ratio and the intercept is $\pi^{2} G^{2}$. It is possible to put $\pi^{1} C_{d}^{1}$ and $\pi^{2} c_{d}^{2}$ on the same axis because they are proportional by the Cobb-Douglas assumption.

The requirement of full employment in period 2 is expressed as the $\mathrm{L}^{-2}$ schedule in quadrant 3 . It will be less (more) steep than the $45^{\circ} 1$ ine as the non-traded goods sector is more (less) capital intensive than the traded goods sector. The equation of this schedule is $\lambda_{d}^{2} K_{d}^{2}+\lambda_{f}^{2} K_{f}^{2}=L^{2}$, where $\lambda_{i}$ represents the labor-capital ratio in sector $i$, which is determined by factor prices. The level of investment can be read as the vertical distance between the $L^{2}$ schedules and the $45^{\circ}$ line's $K_{f}^{2}$ intercept.

The schedules in Figure 2 along with the factor price frontiers in Figure 1 serve to fully characterize equilibrium. Notice finally that the current account, CA, is given by $S-I$ which can be read from Figure 2 .

\section{Savings Incentives}

At this point, we are ready to consider the effects of policy changes. The effect of a decrease in period 1 public consumption is depicted in Figure 3. As already noted, the relative price of non-tradeables, $\pi$, declines. Employment in the traded goods sector increases, while decreasing in the non-traded sector. National savings increases. None of the schedules in the other quadrants shifts. It is apparent that in the long run 


\section{Figure 4}

The Effect of an Investment Incentive

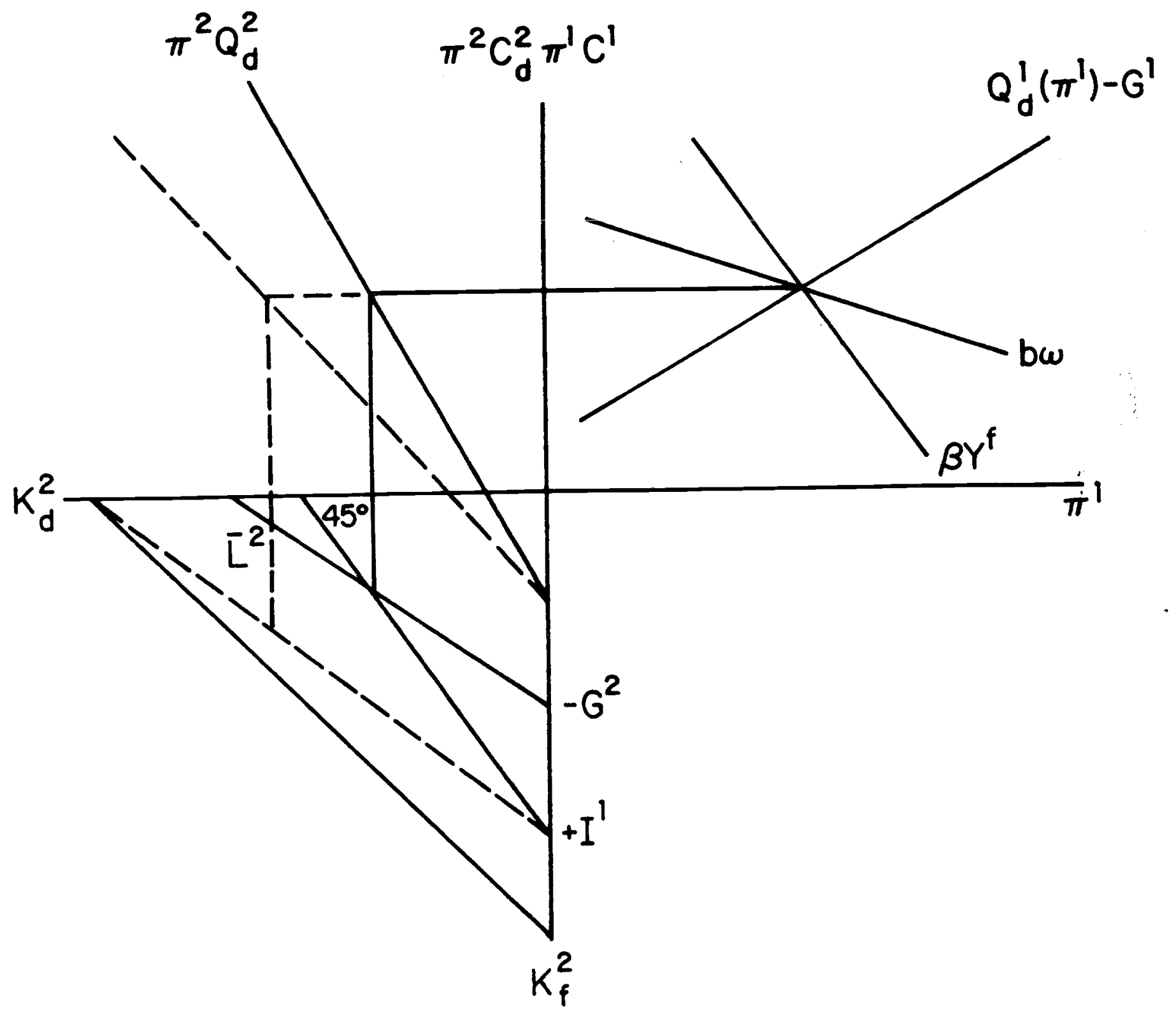


$K_{d}^{2}$ increases and $K_{f}^{2}$ decreases. Since capital labor ratios are unchanged, it follows that employment in the traded goods sector will decline in the long run after its initial increase. Investment will increase (decrease) as the traded goods sector is less (more) capital intensive than the non-traded goods sector. As long as the non-traded goods sector is not "far" more capital intensive than the traded goods sector, savings will increase more than investment and a current account surplus will result.

The effects of a decrease in $\theta$, which reduces private consumption, parallel those of a reduction in public consumption. They cannot be neatly analyzed diagrammatically because a change in $\theta$ breaks the proportionality between $\pi^{1} c_{d}^{1}$ and $\pi^{2} c_{d}^{2}$. Note however that the effect of a savings incentive will be to raise $\pi^{2} c_{d}^{2}$, and give rise to second period effects very similar to those of a change in government spending. The traded goods sector will expand in the short run and contract in the long run. Investment may rise or fall but it is unlikely to change a great deal.

\section{Investment Incentives}

The effects of an investment incentive, treated here as a decline in $T$, are depicted in Figure 4. The solution is most easily achieved working backwards. It is clear that with capital mobile, the long run effect of an investment incentive will be to raise capital intensity in both production sectors and to raise real wages. Thus the $\mathrm{L}^{2}$ schedule in the third quadrant shifts downwards. The shift will be parallel in the special case depicted here where the elasticities of substitution in the two sectors are equal. The capital output ratio in the domestic goods sector must increase shifting the 
$\pi^{2} c_{d}^{2}$ schedule down and to the left. Finally, the increase in second period real wages increases human wealth and shifts the $b \Omega$ schedule in the first quadrant upwards.

The effect of an investment incentive is to reduce short run competitiveness, and to reduce domestic savings. Long run capital intensity is increased, so the current account unambiguously declines. An investment incentive has an ambiguous effect on $\pi^{2}$, the relative price of non-tradeables, depending on the relative capital intensities of the two sectors. In the special case where the two sectors have equal capital intensity, an investment subsidy will increase long run employment in the traded goods sector. More generally, however, the result is ambiguous.

In assessing the implications of this theoretical analysis, a crucial question arises. How much real time corresponds to the short and long run in the stylized two period model considered here? The issue is difficult to judge but it seems likely that the model's short run predictions are applicable over fairly long horizons. Policies directed at increasing the domestic capital stock are likely to lead to increased net investment for many years as new capital is accumulated. The available evidence, while weak, suggests that capital adjusts relatively slowly to its desired level. Likewise simulations of the type presented by Summers (1979) and Chamley (1981) suggest that households will take periods of up to a decade to fully adjust their wealth holding following a change in the available rate of return. These considerations suggest that with a horizon of a decade or less it is probably appropriate to use the short run predictions of the economy to tax reforms. The simulation results of Lipton and Sachs (1983) are consistent with this suggestion. 


\section{The Political Economy of International Competitiveness}

The arguments of this section raise an obvious question. Why is business tax relief so frequently advocated as a vehicle for increasing international competitiveness? The analysis here suggests that tax reduction measures, which encourage investment, inevitably reduce competitiveness and hurt firms in the traded goods sector as long as capital is mobile internationally. In part, advocacy of tax relief must result from a failure to consider its general equilibrium ramifications. With fixed real exchange rates, tax relief does help the traded goods sector. Its advocates may fail to take account of the increase in real exchange rates that necessarily accompanies capital inflows. But economists should be reluctant to assume that self interested parties are advocating positions contrary to their interests. It is therefore worthwhile to consider other reasons why those in the traded goods sector might advocate tax relief.

A first possibility is that they are motivated by long run considerations. Accumulating debt to foreigners will eventually require that we run a trade surplus. But it seems unlikely that such a long run consideration plays an important role in current policy debates. A second explanation starts with the recognition that the traded goods sector is not monolithic. Tax reforms which benefit firms in some but not all of the traded goods sector may cause their competitiveness to increase even as the total traded goods sector is shrinking. It might for example be argued that incentives to invest in plant and equipment benefit American manufacturers at the expense of farmers. The corporate sector is so large a fraction of the traded goods sector that it seems unlikely that this is the whole story. 
A third explanation for the advocacy of investment incentives to increase competitiveness is that advocates suspect that investment incentives will not in fact lead to prolonged capital inflows. This may be because capital mobility is limited and so investment incentives will lead to only small capital inflows. Alternatively, it may be because governments are perceived as unlikely to permit large trade deficits to continue for long periods of time. In either of these cases, tax incentives will raise the after tax profits of firms in the traded goods sector and will not lead to significant declines in competitiveness. I explore the question of the extent of international capital mobility in the remainder of the paper.

\section{National Savings and National Investment}

The preceding section demonstrated that the assumption of perfect international capital mobility has important implications for the analysis of competitiveness. It also is important for other fiscal questions. With internationally mobile capital, taxes on investment will all be borne by labor. Government budget deficits will not affect national levels of investment, but will instead reduce investment around the world. More generally, policies which increase national savings will have no effect on national investment.

In provocative recent papers, Feldstein and Horioka (1980) and Feldstein (1983) point out that if national savings do not affect national investment as the capital mobility hypothesis implies, one would not expect to see any strong relationship between national savings and investment rates. Yet, as 
Table 1 demonstrates, there is a very close association between levels of national savings and national investment. While the long run average net savings rate varied across countries between 6.5 and 19.6 percent, the largest average current account deficit was 8.3 percent and the largest surplus was only 2.3 percent. The correlation between domestic savings and investment rates was .92 .

Table 2 presents regressions of the national investment rates on national savings rates for a number of different intervals. Using both net and gross measures, the data suggest a strong relationship between investment and savings. 2 In all cases, the savings variable is highly significant. It is noteworthy that there is no evidence that the impact of national savings on national investment has declined through time, even though institutional barriers to international capital mobility have been broken down over the past 25 years. There is some evidence however that the correlation between savings and investment rates has declined through time.

Comparisons of the size of actual capital flows with those that might be expected highlight the apparent immobility of capital. Consider a policy which raises the return on domestic investment by 20 percent. This is about the right order of magnitude for the 1981 and 1982 United States tax reforms. Assuming a Cobb-Douglas production function with a capital share of .25 , an increase of about 20 percent in the capital stock would be required to equalize the return on domestic and international investment. With a capital output ratio of 1.5 , this would mean a capital inflow of close to 30 percent of GNP. Only one OECD nation, Portugal, experienced a capital inflow of this magnitude over the 1975-1981 period. Stating the point differently -- the 
capital flows that are observed do not seem to be large enough to have very large effects on rates of return.

A number of papers including Sachs (1981, 1982), Feldstein (1983), and Caprio and Howard (1984) have examined the relationships between changes in domestic savings and investment rates. While the approaches taken in these papers differ somewhat, several conclusions emerge. There is a positive relationship between changes in domestic savings and changes in domestic investment which is weaker than the relationship between savings and investment levels. Also, it appears that both shocks to domestic savings and to domestic investment have significant effects on the current account although their relative importance is a subject of debate. Finally, there is very weak evidence that the degree of international capital mobility has increased somewhat in recent years. But, none of the time series analysis calls into question the proposition that domestic savings and investment rates are closely linked.

One consideration that could account for some degree of association between domestic savings and investment rates is the fact that countries are not perfectly "small" on the world capital market. A share of each country's savings would be invested in it, even if capital was perfectly mobile. It seems unlikely that this can account for a large part of the correlation between savings and investment rates. Even for the United States, a dollar of savings would be expected to produce only about 25 or 30 cents of domestic investment if capital were really perfectly mobile. Moreover, this point has no force in considering the cross-sectional association between domestic savings and investment rates. 
Another possible source of association between domestic savings and investment is Keynesian effects. Increases in investment which raise domestic income temporarily would be expected to increase domestic savings as well. The fact that savings and investment rates are about equally highly correlated over short and long periods of time suggests that this is not likely to be too important a factor.

It is not clear how to interpret the observation that savings and investment rates are highly correlated across countries. The questions of policy interest concern the allocation of the marginal dollar of domestic savings, or the financing of a marginal dollar of domestic investment. It is conceivable that incremental savings are invested in a very different way than the average dollar of savings. The fact that the linkages between changes in savings and changes in investment are weaker than those between levels suggests this view. An argument of this kind must explain however why ongoing capital flows are not observed between countries with stable high and low savings rates. In the next section we consider alternative explanations for the close association between savings and investment rates across nations. These explanations have differing implications for the hypothesis of marginal capital mobility and for the effects of fiscal policies.

\section{Explaining Apparent Capital Mobility}

The previous section documented the very high correlation between national savings and investment rates. This section considers three possible explanations for this phenomenon. These explanations assume in turn that 
capital mobility is greatly limited by institutional factors, that the correlation between national savings and investment rates is a spurious reflection of third factors, and that apparent capital immobility reflects the endogenous adjustment of savings and investment rates. While there is some element of truth in each of these explanations we are led to accept the third one as the primary reason for the close association of domestic savings and investment rates.

\section{Capital Immobility}

A first natural explanation for the observed savings and investment patterns is that most capital is immobile. While some capital can flow freely, restrictions in financial institutions, capital controls, and the perceived risks of foreign investment, greatly reduce the flow of capital. As Feldste in and Horioka (1980) suggest,

"official restrictions impede the export of capital. Moreover the fear of future capital export controls by potential host countries... deters investors.... Important institutional rigidities also tend to keep a large segment of domestic savings at home. The most obvious of these in the United States is the savings institutions that are required by law to be invested in mortgages on local real estate."

There is, of course, a large pool of very liquid international capital. The argument, however, is that only this money is freely mobile with other savings being immobile. This raises an immediate problem. If only a small pool of "hot money" were available to arbitrage large international return differentials, one would expect that it would all end up in one place. As long as some mobile funds are located almost everywhere there is a presumption that rates of return must be equalized.

The related argument of Feldstein and Horioka that returns on short term 
financial assets are arbitraged but returns on longer term investments are not equalized is also difficult to accept. Arbitrage like equality is transitive. As long as there are institutions in each country (e.g., Citibank) which hold different types of domestic assets and also hold some foreign asset, we can be sure that the returns on domestic and foreign assets are arbitraged. Equalization of returns does not require that there be any agent who makes long term investments both at home and abroad. As long as the standard assumption of marginal domestic capital mobility is maintained, the existence of investors at interior solutions holding any domestic and any foreign assets is sufficient to insure marginal capital mobility on an international basis. 3

A clear piece of evidence suggesting the mobility of capital internationally is the fact that the relatively small net flows of capital that are observed reflect large offsetting gross flows. If capital were immobile one would expect to see small gross as well as net flows. Unfortunately data on foreign investment by domestic firms and domestic investment by foreign firms are not available on a consistent international basis. Therefore, Table 3 presents some information on gross and net flows of investment for the United States. In 1982, both capital inflows and outflows for the U.S. Were more than ten times the net flow of capital. Even these figures underestimate the true flows because they fail to take account of replacement investment by Americans abroad and foreigners here.

Large reciprocal gross investment flows also call into question Feldstein's (1983) argument that subjective uncertainties inhibit capital flows. Feldstein and Horioka argue that foreign investment is typically directed at exploiting specialized opportunities rather than the general 
pursuit of higher returns. This claim is difficult to reconcile with the large volume of portfolio investment and with Hartman's (1983) demonstration that foreign direct investment is very sensitive to tax considerations. Recall that no foreign direct investment is necessary for international arbitrage to equalize returns. Even granting that direct foreign investments represent special situations, it is still reasonable to expect that increased domestic savings which reduce domestic rates of return would lead to more specialized foreign investments.

This discussion suggests that there exist capital flows which seem to have the potential to equalize rates of return around the world. A more subtle explanation for capital immobility, which accommodates this observation, might suggest that total net capital mobility is limited by fears of expropriation. This is the essential idea lying behind the burgeoning literature on international debt. It was first treated formally by Eaton and Gersovitz (1981). While capital can be freely moved, investors are aware that if a country has imported too much capital, the gains from expropriating it will exceed the costs that can be imposed. In this case, marginal investors will not invest abroad even if foreign assets are yielding higher returns. At the margin, capital will be immobile. Changes in domestic saving will affect international capital flows only insofar as they affect countries' debt capacity by affecting the size of the "punishment" that can be inflicted on them for defaulting.

It would seem likely that arguments of this type would be more applicable to LOCs than to the OECD nations, where expropriations seem implausible. One way of testing this explanation for apparent capital immobility is to examine 
the association between savings and investment across a broad range of countries. If expropriation fears were a major cause of capital immobility, one would expect to see savings and investment rates even more closely associated among LDCs than among the OECD nations. This hypothesis was tested by examining data on national savings and investment rates for 115 countries using data provided by the World Bank.

A regression of investment rates on savings rates using data arranged over the 1973-80 pertod yields:

$$
I / Y=\frac{18}{(1.1)}+\underset{(.051)}{.311(5 / Y)} \quad R^{2}=.24
$$

These results were almost unchanged when the OECD countries were excluded from the sample. As a further check, the equation was reestimated dropping observations with large residuals from the sample. Observations with residuals with absolute value greater than two and three times the standard error of the regression were omitted. This did not have a significant impact on the results. One possible explanation for the low correlation between savings and investment is that aid flows drive a wedge between investment and savings even though capital is immobile. However, subtracting aid flows from investment had little impact on the results. It wight be argued that the low correlation between domestic savings and investment is the result of measurement error. This seems unlikely. In most cases, domestic savings is estimated as a residual. When this method is used, measurement error may result in a spurious positive correlation between measured savings and investment. The results suggest a much greater degree of apparent capital mobility 
when a large sample of countries is considered. Similar results are reported by Fie leke (1982) and Frankel (1985). This provides evidence against the hypothesis of capital immobility which offers exactly the wrong predictions -that capital should be most mobile between politically allied developed countries with well functioning capital markets.

It does not seem reasonable to conclude that capital immobility is the right way to explain the close association between national savings and investment rates. I therefore turn to other explanations.

\section{Common Factor Explanations}

Another possible explanation for the close association between national savings and investment rates is the fallacy of the common cause. Perhaps there is some third factor which determines both savings and investment leading them to be highly correlated, even though exogenous changes in savings would have only very small effects on investment. Two such factors suggest themselves. Countries with high rates of population or productivity growth would be expected to have high investment rates because of the opportunities created by a rapidly growing labor pool. Life cycle savings considerations suggest that such countries should also have high savings rates, as young savers are more numerous and have more lifetime income than older dissavers. Thus growth could be a common factor accounting for associations between savings and investment. Obstfeld (1985) provides a rather elaborate example illustrating this point.

A second factor which could lead to a positive association of savings and investment is initial wealth. A clear example is provided by a nation ravaged 
by war. Such a country would be expected to have a high investment rate because of the destruction of its capital stock, and a high savings rate because of households' desire to rebuild their wealth holdings. Any source of initial differences in national wealth income ratios would tend to work the same way.

The growth explanation for the strong association between savings and investment rates is easily tested. It is only necessary to add measures of the rate of growth to a regression of the investment rate on the savings rate.

A regression of the net investment rate on the net savings rate and the rates of population growth and productivity growth using the data in Table 1 yie lds:

$$
I / Y=\frac{-.015+1.02 \mathrm{~S} / \mathrm{Y}-\frac{.002 \mathrm{n}}{(.023)+(1.39)}+\frac{.0026 \mathrm{~g}}{(.01)}(.001)}{(.01)} \quad \mathrm{R}^{2}=.703
$$

Similar results are obtained reversing the equation, using gross rather than net concepts and varying the sample period. Adding growth variables actually increases the coefficient on $S / Y$. This implies that variations in savings that are uncorrelated with variations in growth actually have more relation to investment than variations explained by the growth variables. Growth is not the spurious factor accounting for the strong correlations between national savings and investment rates.

There is no single variable which can capture the possible effects of initial conditions on both savings and investment. Therefore it is necessary to take a more indirect approach. Estimating the basic investment-savings 
relationship with instrumental variables, using as instruments any variable expected to affect savings but not investment, will yield a consistent estimate of the "pure" correlation between savings and investment. Feldstein and Horioka report a number of estimates of this type using social security variables as instruments. They find that this has little effect on the estimated savings coefficient. Indeed, in several cases it actually increases. Frankel (1985) presents some corroborating evidence.

In order to further examine this issue, the basic savings investment relationship was reestimated using the government budget deficit as an instrument. Because of data limitations, a smaller sample (14 countries) and a shorter time period (1973-80) were used in the estimation. For this sample the net result of an OLS regression was:

$$
I / Y=\frac{.02+.97(S / Y)}{(.03)(.13)}
$$

Using the government deficit as a share of GDP as an instrument, the result was:

$$
I / Y=-.10+1.45(S / Y)
$$

This result is surprising. The coefficient on the savings variable rises substantially rather than declining. It attains an implausible value exceeding one. On the "spurious factor" explanation, one would have expected the savings coefficient to decline.

There is no evidence here to support the "spurious factor" explanation for the close association of national savings and investment rates. But the 
last equation does raise a puzzle. Why should purging the savings and investment variables of the effects of their common causes cause their estimated association to increase? Clearly the answer must have something to do with the properties of the deficit variable. This issue is explored in the next subsection.

\section{The Maintained External Balance Hypothes is}

The assumption has been made so far that national savings and investment rates are exogenously determined. Feldstein and Horioka treat differences in national savings rates as a consequence of "basic structural differences among countries." In their formal model (p. 324), the level of public savings is an exogenous variable affecting the national savings rate.

An alternative view is that countries consistently manipulate the levels of economic policy with a view to maintaining external balance. Such an argument has been made by Fieleke (1982) and Tobin (1983) among others. In this case capital appears immobile only because countries pursue policies which bring savings and investment into balance. Possible rationales for this behavior are discussed below.

The endogeneity of budget policy can easily explain the empirical results in the preceding section. Consider the special case where capital is completely mobile on world markets and countries set budget deficits according to:

$$
D_{i}=\alpha\left(P S_{i}-I_{i}\right)+u_{i} \text {, with } 0 \leqslant \alpha \leqslant 1
$$

where $D_{i}$ is the deficit, $P S_{i}$ is private saving, and $u_{i}$ represents the effect of other factors on the deficit of country $i$. The assumption that deficits 
are exogenous corresponds to $\alpha=0$ in this formulation. Standard calculations suggest that the coefficient on saving in our basic equation will equa 1:

$$
\hat{\delta}_{\mathrm{OLS}}=\frac{(1-\alpha) \sigma_{\mathrm{PS}, I}+\alpha \sigma_{I}^{2}}{(1-\alpha)^{2} \sigma_{\mathrm{PS}}^{2}+\alpha^{2} \sigma_{I}^{2}+2 \alpha(1-\alpha) \sigma_{\mathrm{PS}, I}+\sigma_{\mathrm{U}}^{2}}
$$

Notice that in the special case where $\alpha=1$ and $\sigma_{u}^{2}=0, \hat{\delta}=1$, and that with Feldstein and Horioka's implicit assumptions that $\alpha=0$ and $\sigma_{\mathrm{PS}, \mathrm{I}}=0$ in a perfect capital market, $\hat{\delta}=0$. As these polar cases suggest, increases in $\alpha$ and reductions in $\sigma_{u}^{2}$ will tend to raise the value of $\hat{\delta}$. Direct estimation of (9) yields:

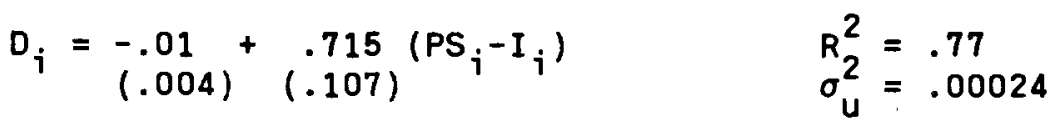

Using this estimated value of $\alpha$ and the observed sample moments tautologically yields the OLS estimate for $\delta$. If we reevaluate (10) assuming that $\alpha=0$ and that $\sigma_{u}^{2}=\sigma_{d}^{2}$, the implied value of $\delta$ is .597 . This confirms that some of the strength of the Feldstein and Horioka results arises from deficit policy actions directed at maintaining external balance. Note that Feldstein (1983) admits that some positive association between PS $_{i}$ and $I_{i}$ is to be expected, arising from factors such as growth rates which simultaneously impact both PS $i$ and $I_{i}$. And other policy levers besides deficits may be used to bring savings and investment into balance. Hence the remaining correlation of .6 should not be treated as evidence of the immobility of capital. 
The maintained external balance hypothesis also explains the paradoxical results obtained when $D_{i}$ is used as an instrument. In this case, the probability limit of the coefficient of interest is given by:

$$
\hat{\delta}_{I V}=\frac{\sigma_{D, I}}{\sigma_{D, S}}=\frac{\alpha \sigma_{I}^{2}-\alpha \sigma_{P S, I}}{\alpha^{2} \sigma_{I}^{2}-\alpha(1-\alpha) \sigma_{P S}^{2}+\alpha(1-2 \alpha) \sigma_{P S, I}+\sigma_{U}^{2}}
$$

which will be greater than unity as long as:

$$
\alpha(1-\alpha) \operatorname{var}(I-P S)>\sigma_{u}^{2}
$$

The estimates of $\delta_{I V}$ and $\sigma_{U}^{2}$ reported above imply that this condition is satisfied in practice.

This section has shown that the maintained external balance hypothesis can explain how the observed high correlation of national savings and investment rates could occur in a world with perfect capital mobility. It also explains an additional finding, the high degree of capital mobility among less developed countries, which is anomalous on the view that capital is internationally immobile. In these nations the pressure to maintain external balance is much weaker, and so fiscal policy actions are not taken to prevent capital flows. As a consequence, greater current account imbalances and capital mobility are observed.

The maintained external balance hypothes is seems on the bas is of the evidence considered here to be the most plausible explanation for the high cross-sectional correlation between domestic savings and investment rates. By its nature it is difficult to test, since levels of national savings and 
investment are affected by a wide variety of policy levers, and so the stance of policy towards saving and investment in any given country is difficult to evaluate. Below, I discuss a number of plausible reasons why nations might seek to maintain external balance. The fact that countries so frequently resort to capital controls which force savings and investment into balance makes it very plausible that they also use other policy levers to achieve the same purpose.

Capital will be effectively immobile internationally if nations act so as to avoid either capital outflows or capital inflows. Either would be sufficient to preclude capital flows. Consider first the incentives nations might have to avoid capital outflows. The fundamental reason why nations might prefer to do this is that the social return to domestic investment exceed the social return to foreign investment even when their private returns are equated. Most obviously, this will be the case where there are taxes on domestic investment. More subtly and more importantly, there is the risk associated with capital expropriation by government action or by labor. 4 Keynes (1924) puts the argument we11:

"Consider two investments, the one at home and the other abroad with equal risks of repudiation or confiscation or legislation restricting profit. It is a matter of indifference to the individual investor which he selects. But the nation as a whole retains in the one case the object of the investment and fruits of it; whilst in the other case both are lost. If a loan to improve South American capital is repudiated we have nothing. If a Poplar housing loan is repudiated, we as a nation still have the houses."

Note that the phrase "legislation restricting profit" covers a host of possibilities far short of outright nationalization. There is also the possibility that capital expropriation will take the form of actions by 
workers to raise wages and capture the rents that can be earned from irreversible capital investments. Together these possibilities seem likely to be of substantial importance. They provide a motivation for countries which find themselves exporting capital on a substantial scale to pursue measures directed at spurring domestic investment. In so far as they suggest that the social return to fareign investment may be rather low, they also suggest the possible desirability of reducing savings when they are primarily flowing abroad. Certainly this was Keynes's view regarding the huge British capital outflows in the early part of this century.

It is noteworthy in this regard that capital exporting nations tend to be large countries with substantial international power. The British in the Victorian era and the us during the post World War II period are obvious examples. The current Japanese situation is less clear. Where capital outflows are made by dominant international powers they may confer external benefits which raise their social return by increasing international influence. Large countries may also regard themselves as relatively immune from expropriation risks. The striking feature of Table 2 is that almost all of the small countries are capital importers. With large countries unwilling to export capital in large quantities however, the scope for international capital mobility is relatively limited.

Keynes went on to provide an additional reason why a nation might want to limit its capital exports. 5 He wrote that

"Foreign investment does not automatically expand our exports by a corresponding amount. It so affects the foreign exchanges that we are compelled to export more in order to maintain our solvency. It may be the case--I fancy that it now is the case--that we can only do this by lowering the price of our products in terms of the products of other nations, that is by allowing the ratio of real interchange to move to our disadvantage." 
This consideration which is important only for countries with some market power may also help to explain why large capital outflows are so rare. A possible example is provided by the efforts of the United States to limit capital outflows in the early 1960s in an effort to maintain the value of the dollar. Whether the motivation for maintaining the value of the dollar was enjoying favorable terms of trade is not clear.

There are also reasons why countries would be reluctant to accept large capital inflows. Where these are associated with large movements in real exchange rates, they are likely to damage severely an economy's traded goods sector. This may generate political pressures to increase domestic savings or to reduce the rate of investment. These pressures are likely to be particularly serious in situations where the real exchange rate changes quickly or where the traded goods sector is not benefiting from the capital inflows. It should not be surprising that capital inflows into Canada to finance development of its natural resources have proved more politically acceptable than recent inflows into the United States to finance budget deficits.

These arguments are suggestive as to why we see such a small volume of net international capital mobility. Evaluating their relative importance is left for future research. In the next section, we tentatively accept the ir validity and explore their implications for economic policy. 


\section{Conclusions}

Our analysis of the historical experience of the last twenty years suggests that capital was internationally mobile but that governments acted so as to permit only relatively small capital flows. This makes it difficult to analyze the effects of tax policy changes. Such changes, if not accommodated by other policies, would lead to significant capital flows with associated implications for competitiveness. But the historic record suggests that policy changes would be adopted to maintain external balance. If such changes are always adopted, capital is effectively immobile. National investment cannot be increased without increasing national savings. The effect of any policy depends on the policies it engenders. Consider, for example, an investment tax credit. The resulting capital inflow would lead to a trade deficit. If this created pressures which led to an increase in public savings, the ultimate result would be more domestic investment and only small effects on the traded goods sector. If, on the other hand, other countries responded to their capital outflows by strengthening capital controls, the result would be increased domestic interest rates and only relatively small investment increases. In this case short run competitiveness might actually be improved by investment tax incentives.

clearly there are no general principles which can be used to assess the effects of different policies in all situations. Neither the analytic benchmark of perfect capital mobility, nor the polar opposite assumption that capital is immobile seems appropriate in assessing the effects of tax reforms. 
These points are well illustrated by considering the current American situation. The dollar is extremely strong, having risen by about 60 percent in the last four years. This has led to the large trade and current account deficits, which are regarded by many observers as a cause for grave concern. Beyond the direct effects on industries producing traded goods, concerns are expressed about the United States becoming a debtor nation, and about a weakening in our national commitment to free trade. Following the Reagan tax incentives, an increase of close to 25 percent in the capital stock would be necessary to bring the after-tax return to capital back to its former level. Since the United States is not a small country on the world capital market, not all of these funds would come from abroad even if capital were perfectly mobile. But with mobile capital, one would have to predict a cumulative current account deficit in excess of 15 percent of GNP in response to the 1981 tax cuts. This is on top of any current account deficit attributable to federal budget deficits. It seems unlikely that such large sustained capital inflows will be allowed to materialize. Some combination of increased savings through reduced budget deficits and expansionary monetary policy is likely to be used to restore external balance. Thus, the recent U.S. experience is in a sense the exception that proves the validity of the maintained external balance hypothesis.

Note finally that the maintained external balance hypothesis resolves the riddle of why firms producing traded goods favor investment incentives. If they expect these incentives to be coupled with other policies directed at stabilizing the current account, they are rational in advocating investment incentives. This is true if investment incentives are accommodated by 
increased public savings expansionary monetary policies, or even protectionist policies. This point may well be illustrated by the evolution of the U.S. economy over the next few years. 


\section{Footnotes}

1. Note that the formulation here requires that capital invested in either sector earn the world rate of return $R$ in period 2. As Frankel (1985) has stressed, there is no reason to expect that real interest rates measured relative to a domestic price index which includes both tradeable and non-tradeable goods will be equalized across countries. Indeed as long as purchasing power parity fails as a description of exchange rate behavior, real interest rates cannot be equalized measured both relative to price changes in tradeable goods, and the domestic consumption basket. In the model considered here despite capital mobility, there is not real interest rate equalization measured in the standard way using general domestic price indices.

2. There is no obvious reason for regressing investment on savings rather than running the reverse regression. The interested reader can compute the coefficient that would be obtained from the reverse regression by dividing the reported coefficient into the regression's $R^{2}$. The reverse regression coefficients tend to be a little smaller than the reported coefficients. 3. Zeira (1986) in a very perceptive analys is notes that this conclusion is only correct if assets are perfect substitutes in individual portfolios. The empirical importance of this qualification is however open to question given the findings of Frankel (1985) that the standard CAPM along with reasonable assumptions regarding risk aversion implies that assets are in fact very close substitutes.

4. I am indebted to Jeff Sachs for bringing Keynes discussion of this issue to my attention. 
5. This argument in many ways parallels the one developed by Roger Gordon in his comment on this paper. 


\section{References}

Blanchard, 0. and Summers, L. 1984. Perspectives on high world real interest rates. Brookings Papers on Economic Activity 2.

Bruno, M. Adjustment and structural change under supply shocks. NBER Working Paper 814. Cambridge, Mass.: National Bureau of Economic Research.

Caprio, G. and Howard, D. Domestic saving, current accounts, and international capital mobility. International Finance Discussion Paper 244 .

Chamley, C. 1981. The welfare costs of capital taxation in a growing economy. Journal of Political Economy (June): 468-96.

Eaton J. and Gersovitz, M. 1981. Debt with potential repudiation: theoretical and empirical anaiysis. Review of Economic Studies.

Feldstein, M. 1983. Domestic savings and international capital movements in the long run and the short run. European Economic Review (March): 129-51.

and Hartman, D. 1979. The optimal taxation of foreign source investment income. Quarterly Journal of Economics. and $C$. Horioka. 1980. Domestic savings and international capital flows. The Economic Journal 90: 314-29.

Fieleke, N. 1982. National saving and international investment. In Saving and government policy. Conference series no. 25. Boston Federal Reserve Bank. 
Frankel J. 1986. International capital mobility and crowding out in the U.S. economy: imperfect integration of financial markets or of goods markets. In How open is the US economy? st. Louis Federal Reserve conference volume.

- 1985. The implications of mean-variance optimization for four questions in international macroeconomics. Journal of International Money and Finance.

Goulder, L., Shoven, J. and Whalley, J. 1983. Domestic tax policy and the foreign sector. In Behavioral Methods in Tax Simulation Analysis, ed. M. Feldstein.

Hartman, D. Domestic tax policy and foreign investment: some evidence. NBER Working Paper 784. Cambridge, Mass.: National Bureau of Economic Research.

Keynes, J.M. 1924. Foreign investment and national advantage. The Nation and Athenaeum (August 9 ).

Lipton, D. and Sachs, J. 1983. Accumulation and growth in a two country model: a simulation approach. Journal of International Economics.

Obstfeld, M. 1985. Capital mobility in the world economy: theory and measurement. Carnegie Rochester Public Policy Conference.

Sachs, J. 1981. The current account and macroeconomic adjustment in the 1970s. Brookings Papers on Economic Activity: 201-82. - 1982. The current account in the macroeconomic adjustment process. Scandinavian Journal of Economics. 
Summers, L. 1979. Tax Policy in a Life Cycle Mode1. NBER Working Paper 302. Cambridge, Mass.: National Bureau of Economic Research.

Zeira, J. 1986. Risk and the current account. Mimeographed. 
Table 1: Net Savings and Investment (1960-1983)

\begin{tabular}{|c|c|c|c|}
\hline Country & $\begin{array}{l}\text { Net Savings } \\
\text { GDP }\end{array}$ & $\begin{array}{l}\text { Net Investment } \\
\text { GDP }\end{array}$ & $\begin{array}{l}I-S \\
\text { GDP }\end{array}$ \\
\hline U.S.A. & .065 & .066 & .001 \\
\hline Iceland & .071 & .113 & .042 \\
\hline U.K. & .074 & .070 & -.004 \\
\hline Sweden & .008 & .102 & .013 \\
\hline Ireland & .091 & .174 & .083 \\
\hline Canada & .098 & .110 & .012 \\
\hline Denmark & .098 & .128 & .030 \\
\hline Belgium & .105 & .115 & .010 \\
\hline Spain & .108 & .122 & .014 \\
\hline Finland & .110 & .124 & .014 \\
\hline Italy & .112 & .115 & .003 \\
\hline France & .112 & .121 & .009 \\
\hline Turkey & .118 & .153 & .035 \\
\hline Norway & .126 & .144 & .018 \\
\hline Germany & .129 & .124 & -.005 \\
\hline Nether 1 ands & .142 & .129 & -.013 \\
\hline Austria & .145 & .152 & .007 \\
\hline Australia & .146 & .165 & .019 \\
\hline New Zealand & .150 & .188 & .038 \\
\hline Greece & .155 & .179 & .024 \\
\hline Switzer land & .182 & .159 & -.023 \\
\hline Portuga 1 & .191 & .265 & -.074 \\
\hline Japan & .196 & .191 & -.003 \\
\hline
\end{tabular}

Source: OECD. 
Table 2: The Correlation Between National Investment and National Savings

\begin{tabular}{|c|c|c|c|}
\hline Period & Intercept & $\mathrm{s}_{i}$ & $\mathrm{R}^{2}$ \\
\hline \multicolumn{4}{|c|}{ (Net) } \\
\hline $1960-1964$ & $\begin{array}{l}.015 \\
(.013)\end{array}$ & $\begin{array}{l}.962 \\
(.095)\end{array}$ & .821 \\
\hline $1965-1969$ & $\begin{array}{c}.043 \\
(.016)\end{array}$ & $\begin{array}{l}.750 \\
(.106)\end{array}$ & .687 \\
\hline $1970-1974$ & $\begin{array}{l}.042 \\
(.017)\end{array}$ & $\begin{array}{l}.777 \\
(.099)\end{array}$ & .733 \\
\hline $1975-1979$ & $\begin{array}{l}.025 \\
(.024)\end{array}$ & $\begin{array}{l}.941 \\
(.185)\end{array}$ & .528 \\
\hline $1980-1983$ & $\begin{array}{l}.024 \\
(.018)\end{array}$ & $\begin{array}{c}.960 \\
(.164)\end{array}$ & .586 \\
\hline \multicolumn{4}{|c|}{ (Gross) } \\
\hline $1960-1964$ & $\begin{array}{l}.029 \\
(.017)\end{array}$ & $\begin{array}{l}.920 \\
(.073)\end{array}$ & .879 \\
\hline $1965-1969$ & $\begin{array}{c}.047 \\
(.023)\end{array}$ & $\begin{array}{l}.834 \\
(.093)\end{array}$ & .783 \\
\hline $1970-1974$ & $\begin{array}{l}.049 \\
(.026)\end{array}$ & $\begin{array}{l}.835 \\
(.106)\end{array}$ & .755 \\
\hline $1975-1979$ & $\begin{array}{l}.065 \\
(.042)\end{array}$ & $\begin{array}{l}.789 \\
(.185)\end{array}$ & .439 \\
\hline $1980-1983$ & $\begin{array}{l}.086 \\
(.032)\end{array}$ & $\begin{array}{l}.679 \\
(.152)\end{array}$ & .464 \\
\hline
\end{tabular}


Table 3: Net and Gross Flows in the U.S.

(Billions of $\$$ )

\begin{tabular}{|c|c|c|}
\hline & 1981 & 1982 \\
\hline Current Account Balance* & 4.5 & -8.1 \\
\hline Net Foreign Investment & 4.1 & -4.6 \\
\hline $\begin{array}{l}\text { Increase in U.S. Assets Abroad** } \\
\text { (capital outflows) }\end{array}$ & 109.3 & 118.3 \\
\hline $\begin{array}{l}\text { Increase in Foreign Assets in the U.S.** } \\
\text { (capital inflows) }\end{array}$ & 77.9 & 84.5 \\
\hline
\end{tabular}

*The Current Account Balance and Net Foreign Investment are ("capitally the same, differing only by the allocations of SDRs differences.

**The net increase over the year; that is, conceptually, the difference between the value of assets at the end of the year and the value at the var's beginning.

The reason that the difference of the gross flows is not equal to the reported net. llows is a sizable statistical discrepancy.

Source: Survey of Current Business, March 1983, pp. 13 and 51. 